This paper was published in the Journal of Beliefs \& Values, 22(1):113-119, 2001, as

Comparing levels of spiritual well-being in State, Catholic and Independent schools in Victoria, Australia

by

Dr John W. Fisher

Research Project Officer

School of Nursing, University of Ballarat

PO Box 663

BALLARAT VIC 3353 Australia

e-mail: j.fisher@ballarat.edu.au

Fax: +61.3.5327.9719 


\title{
Comparing levels of spiritual well-being in State, Catholic and Independent schools in Victoria, Australia
}

\begin{abstract}
This paper reports on a survey completed by Chaplains, Religious Education and Student Welfare Coordinators in State, Catholic and Independent schools in Victoria. Results from this survey support the model of spiritual well-being, which was seen to be reflected in the quality of relationships that people develop with themselves, others, the environment, and with a Transcendent Other. The staff surveyed generally reported positively on current practice and expressed high priorities for action in nurturing their students' spiritual well-being. School type contributed to significant differences in each of these four sets of relationships.
\end{abstract}

\section{INTRODUCTION}

As part of their charter, Australian schools have the responsibility of providing 'a foundation for young Australians' intellectual, physical, social, moral, spiritual and aesthetic development' (MCEETYA 1999). Although there are some encouraging signs about the physical health of young people in Australia (Moon, Meyer \& Grau 1999), signs of emotional and psychological health are not as positive. The rate of suicide among 12-24 year-olds has increased over the period from 1979 to 1997, particularly for males. Moon et al. (1999) reported that, even though the rates of "successful" suicides was higher for males, more females are clinically depressed than males and the parasuicide rate is also higher for young females than males. These results may indicate that there are still too many young people in Australia who lack a clear sense of meaning, purpose and direction in life. These are all key elements of spiritual well-being. For example, research studies with college students have shown a relationship between spiritual well-being and depression (Fehring et al. 1987) and between spiritual well-being and psychological well-being (Barcus 1999). 
Spiritual well-being has been conceptualised as harmonious relationships - with self, others, God, and the world (National Interfaith Coalition on Aging, 1975 in Ellison 1983). From an analysis of recent literature, it can be seen that these four sets of relationships are mentioned to varying degrees in discussions of spirituality, spirituality and health, and spiritual health. Fisher (1999) expanded the NICA statement in light of a literature search and his research to describe spiritual well-being as a fundamental dimension of people's overall health and well-being, permeating and integrating all the other dimensions of health (i.e. the physical, mental, emotional, social and vocational). In addition, he proposed that spiritual health is a dynamic state of being, shown by the extent to which people live in harmony with:

* themselves (i.e. stated meaning, purpose and values in life);

* others (as expressed in the quality and depth of relationships, relating to morality, culture and religion);

* the environment (beyond care and nurture for the physical and biological, to a sense of awe and wonder; for some, the notion of unity with the environment); and

* some-thing/some-One beyond the human level (i.e. ultimate concern; cosmic force; transcendent reality; or God - through Faith).

These four sets of relationships are seen as being contained within corresponding domains of spiritual well-being, namely the Personal, Communal, Environmental and Transcendental domains. Spiritual wellbeing is reflected by the quality of relationships that people have in one or more of these four domains. The choice as to which of these domains is important for spiritual well-being is influenced by the worldview and beliefs of each person.

Through interviews, Fisher (1999) found that teachers in three types of schools expressed marked differences within the four domains of spiritual well-being, the most obvious of which was related to religious pursuits. Catholic schools are less homogeneous than they used to be when the Catholic religious constituted the majority of the teaching staff. Miedema (2000) reported that in the US in the last five years 'links between Catholic primary and secondary teachers and religious communities have (also) 
become weaker.' In Australia, however, many Catholics and Protestants have injected religious fervour into teaching in Catholic schools in keeping with the goal outlined by Dorman (1999) of the 'role of Catholic schools in developing and maintaining positive attitudes towards Christianity.' Independent schools in Victoria range from traditional schools with a religious base which offer Chapel services and possibly RE from a predominately Christian-values perspective, through to fundamentalist Christian schools which enrol only children of 'practising-Christian’ parents. In Victoria, State schools are secular. However, each State school in this study was serviced by a chaplain who is financially supported by the Council for Christian Education in Schools in Victoria, local churches and the school community.

Chaplains/RE Coordinators and Student Welfare Coordinators are charged with oversight of the religious and social and emotional welfare, and often the pastoral care, of students in their schools. They were chosen for this study because it was expected that their views should reflect considered opinion on factors related to their students’ spiritual well-being.

The research reported here aimed to assess the reliability of a spiritual health measure in three types of schools, and to assess differences between the types of schools.

\section{METHOD}

Fisher's model of spiritual health (1999) was used to develop a questionnaire to gain quantitative feedback about current practice and priority for nurturing students' spiritual well-being in a wide range of schools in Victoria, to see if it corresponded to the previously mentioned results found by interviewing teachers.

Forty items were developed which had the potential to reflect the quality of relationships in four domains of spiritual well-being. Respondents were asked to rate their perceptions of their current practice and priority for Developing each of the items with their students. The items were rated on a five-point Likert scale from very high to very low. 
The questionnaires were sent to Chaplains/Religious Education Coordinators in selected State, Catholic and Independent secondary schools in Victoria. If the school had a Student Welfare Coordinator, or another interested person, a request was made for a second questionnaire to be completed. Overall, replies were received from just under half (48\%) of the schools surveyed. The greatest response rate ( $n=44,61 \%)$ came from staff in State schools, with fewer responses coming from Catholic $(n=51,47 \%)$ and Independent school $(\mathrm{n}=55,38 \%)$ staff.

\section{RESULTS AND DISCUSSION}

\section{Four Domains of Spiritual Well-being}

Factor analysis was used to see if the items grouped together according to the theoretical construct of the Fisher's model (1999). Principal component analysis, using SPSS, confirmed the four domains of spiritual well-being labelled Personal, Communal, Environmental, and Transcendental, representing the four sets of relationships of people with themselves, with others, with the environment, and with a Transcendent Other.

In order to have consistency across factors, the best eight items were retained for each of the Personal, Communal, Environmental and Transcendental subscales. The four resulting factors had alpha values ranging from .873 to .945 , accounting for between 52 and 80 percent of the variance in each factor. The correlation values for all eight items in each factor were greater than .618, well above the minimum acceptable value of 0.4 (details are shown in Appendix A).

When the residual 32 items were factor analysed as a group, the principal component accounting for 45 percent of the variance had an alpha value of .925 with correlation values for all items greater than .55. As well as the four separate domains of spiritual well-being having coherence, the 32 items came together to make a valid overall measure of spiritual well-being.

\section{Current Practice and Priority}


The priority mean scores were all significantly higher $(\mathrm{p}<.001)$ than those for current practice indicating that there is a general desire, on the part of the secondary school staff surveyed, to improve the quality of the four sets of relationships pertaining to their students' spiritual well-being. The scores for current practice and priority for the four domains of spiritual well-being are shown in Table 1.

Table 1. Scores for Current Practice and Priority for Four Domains of Spiritual Well-being, by School Type.

\begin{tabular}{|c|c|c|c|c|c|c|c|c|}
\hline \multicolumn{9}{|c|}{ School type } \\
\hline & \multirow{2}{*}{\multicolumn{2}{|c|}{$\begin{array}{c}\text { State } \\
42\end{array}$}} & \multirow{2}{*}{\multicolumn{2}{|c|}{$\begin{array}{l}\text { Catholic } \\
49 \\
\end{array}$}} & \multirow{2}{*}{\multicolumn{2}{|c|}{$\begin{array}{l}\text { Independent } \\
53\end{array}$}} & \multirow[b]{3}{*}{$\mathrm{F}$} & \multirow[b]{3}{*}{ sig. } \\
\hline $\mathrm{n}$ & & & & & & & & \\
\hline SWB domain & mean & SD & mean & SD & mean & SD & & \\
\hline \multicolumn{9}{|l|}{ Personal } \\
\hline current practice & 3.93 & 0.61 & 4.36 & 0.47 & 4.07 & 0.62 & 5.69 & .004 \\
\hline priority & 4.14 & 0.62 & 4.50 & 0.46 & 4.21 & 0.53 & 5.82 & .004 \\
\hline \multicolumn{9}{|l|}{ Communal } \\
\hline current practice & 4.01 & 0.57 & 4.44 & 0.39 & 4.19 & 0.59 & 7.69 & .001 \\
\hline priority & 4.20 & 0.56 & 4.59 & 0.41 & 4.33 & 0.53 & 7.38 & .001 \\
\hline \multicolumn{9}{|l|}{ Environmental } \\
\hline current practice & 3.21 & 0.81 & 3.78 & 0.67 & 3.41 & 0.76 & 6.92 & .001 \\
\hline priority & 3.43 & 0.81 & 3.90 & 0.73 & 3.53 & 0.73 & 5.09 & .007 \\
\hline \multicolumn{9}{|l|}{ Transcendental } \\
\hline current practice & 2.55 & 1.06 & 3.85 & 0.76 & 3.55 & 1.07 & 21.4 & .000 \\
\hline priority & 3.02 & 1.06 & 4.05 & 0.84 & 3.71 & 1.08 & 12.2 & .000 \\
\hline
\end{tabular}

Independent samples T-tests showed that the staff in the Catholic schools reported a greater concern than their counterparts in the State schools for nurturance of their students' spiritual well-being in each of the four domains, both in current practice and priority. Nevertheless, the scores gained by the staff in the State schools, around four on a scale from 1-5, showed they had a high level of concern for their students' well-being in the Personal and Communal domains.

The Catholic school staff expressed greater concern than the Independent school staff in the Personal, Communal and Environmental domains, but equal concern in the Transcendental domain, which reflects the religious ethos upon which the non-government schools were founded. The relative importance of the Transcendental domain for students' spiritual well-being was reflected in the fact that this was the only factor on which the Independent school staff showed greater concern for their students than those in the 
State schools. This is not surprising as the chaplains in the Victorian State schools do not have the same freedom to focus on religious education that is available to staff in Catholic and Independent schools with religious bases. Greater opportunity to focus on RE as well as a greater openness to deal with religious issues across the curriculum in the non-government schools should enhance the Transcendental domain of their students’ spiritual well-being.

The results obtained from this survey correspond well to the findings previously reported on interviews held with staff in the three types of schools in Victoria (Fisher 1999). The spiritual health measure developed in this study has shown itself to be a reliable, convenient, relatively quick way to assess the current practice and perceived priorities that secondary school staff place on nurturing their students' spiritual well-being. A key advantage of using this quantitative measure is that it takes so much less time to administer and process the results and, as has been stated, yields similar results to labour-intensive interviews.

\section{CONCLUSION}

The results of this survey showed that a questionnaire can be used to gain valuable feedback on the four domains of spiritual well-being proposed in Fisher's model of spiritual health. All of the secondary school staff surveyed expressed high levels of concern for their students’ nurturance in the Personal and Communal domains of spiritual well-being. Staff in the Catholic schools expressed consistently high levels of concern for their students' spiritual well-being in each of the four domains, supporting the holistic goal of education in these Catholic schools. The staff in the Independent schools showed a more dualistic response to the issue of spiritual well-being. Although their concerns on the Transcendental/God factor did not differ significantly from staff in the Catholic schools, their concerns for students' spiritual well-being in the other domains (Personal, Communal, and Environmental) were lower than those in the Catholic schools, equating with that of State school staff. 


\section{ACKNOWLEDGEMENTS}

I am most grateful to Rev Peter Whitaker and the Council for Christian Education in Schools, Melbourne, Australia, for the financial support which made this project possible.

\section{REFERENCES}

Barcus, S. M. (1999) The relationship between religious commitment, spiritual well-being, and psychological well-being of college student, $\mathrm{PhD}$ thesis, Ball State University.

Dorman, J. P. (1999) The development, validation, and use of Attitude to Christianity Scales in Australian Catholic schools, Journal of Research on Christian Education, 8(2), pp.291-311.

Ellison, C. (1983) Spiritual well-being: Conceptualization and measurement, Journal of Psychology and Theology, 11(4), pp.330-340.

Fehring, R., Brennan, P. \& Keller, M. (1987) Psychological and spiritual well-being in college students, Research in Nursing \& Health, 10: 391-398.

Fisher, J.W. (1999) Helps to fostering students' spiritual health, International Journal of Children's Spirituality, 4(1), pp.29-49.

Miedema, S. (2000) The aims for religiously inspired urban schools, International Journal of Education and Religion, 1, pp.89-99.

Ministerial Council on Education, Employment, Training and Youth Affairs (1999) The Adelaide Declaration on National Goals for Schooling in the Twenty-First Century (Adelaide: MCEETYA)

Moon, L., Meyer, P. \& Grau, J. (1999) Australia's Young People: Their health and wellbeing 1999 (Canberra: AIHW)

Tillich, P. (1967). Systematic Theology, Volume III: Life and the Spirit History and the Kingdom of God (Chicago: University of Chicago Press) 
APPENDIX A

Factor analyses of Current Practice and Priority for the four domains of spiritual well-being

\begin{tabular}{lll}
\hline Domains of spiritual well-being & Current Practice & Priority \\
\hline Personal & & \\
$\quad$ purpose in life & .790 & .618 \\
life values & .764 & .744 \\
joy & .691 & .762 \\
inner peace & .775 & .719 \\
patience & .721 & .723 \\
sense of identity & .780 & .762 \\
self-awareness & .704 & .692 \\
integrity & .697 & .734 \\
$\quad \%$ variance & 54.9 & 51.9 \\
$\quad$ alpha & .906 & .873
\end{tabular}

\section{Communal}

ethics

.574

.626

forgiveness

.731

sense of justice

.749

empathy

.753

love others

.784

trust

.793

.677

.690

.800

kindness

.732

.845

hope for humanity

.809

.721

$\%$ variance

.715

56.8

alpha

52.6

.903

\section{Environmental}

scenic beauty

.789

.773

positive attitude to environment

.788

awe in nature

.799

.803

environmental concerns

.760

.891

connect with nature

.839

.862

value creation/nature

.789

harmony with environment

.894

unity with environment

.876

$\%$ variance

alpha

69.9

.923

\section{Transcendental}

adore supreme being $\quad .895 \quad 834$

prayer life

.862

.883

worship creator

.904

.899

intune with God

.886

.901

relation with Divine

.914

.914

oneness with God

.933

.908

peace with God

.883

.908

eternal life

.882

$\%$ variance

.872

79.5

alpha

79.9

.940 